\title{
NEW AND LITTLE KNOWN SPECIES OF MOTH FLIES (DIPTERA: PSYCHODIDAE: PSYCHODINAE) FROM NICARAGUA
}

\author{
Jan Ježek ${ }^{1}$, Jozef Oboňa ${ }^{2 *}$, François Le Pont ${ }^{3}$, Peter Manko ${ }^{2}$ and Jean-Michel Maes ${ }^{4}$ \\ ${ }^{1}$ National Museum, Department of Entomology \\ Cirkusová 1740, CZ-193 00 Praha 9 - Horní Počernice, Czech Republic \\ E-mail: jan.jezek@o2active.cz; https://orcid.org/0000-0001-5993-4287 \\ ${ }^{2}$ University of Prešov, Faculty of Humanities and Natural Sciences, Department of Ecology \\ 17. novembra 1, SK-081 16 Prešov, Slovakia \\ E-mails: jozef.obona@unipo.sk; https://orcid.org/0000-0002-1185-658X; *corresponding author \\ peter.manko@unipo.sk; https://orcid.org/0000-0003-1862-9117 \\ ${ }^{3}$ Boulevard Aristide Briand 95, Montreuil Sous Bois, F-931 00, France \\ E-mail: lepont.francois1@bbox.fr \\ ${ }^{4}$ Museo Entomológico, León, Nicaragua. E-mail: jmmaes@yahoo.com
}

The male of a new species Arisemus venustus sp. n. from Nicaragua, the Cerro Musun Natural Reserve, is described. Arisemus atrasetus (Rapp, 1945) and Platyplastinx tango Quate et Brown, 2004 (Diptera: Psychodidae: Psychodinae) from Nicaragua are redescribed and illustrated based on male morphological characters.

Key words: Central America, Nicaragua, non-phlebotomine moth flies, taxonomy, faunistics, new species, Maruinini, Setomimini.

\section{INTRODUCTION}

The genus Arisemus Satchell, 1955 included 33 known species distributed between Mexico and Panama, and several Caribbean islands (Bahamas, Cuba, Jamaica, Puerto Rico) (see Satchell 1955, Botosaneanu \& Vaillant 1970, VailLANT 1986, Wagner \& Joost 1994, Quate 1996, Wagner \& Masteller 1996, Collantes \& Martinez-Ortega 1999, Collantes \& Baquero 2000, Quate \& Brown 2004, Bravo \& Araújo 2013, Bejarano \& Estrada 2016, Ibañez-Bernal \& SuÁrez-LANDA 2017). The last two coauthors discussed the taxonomic history of this genus and differences of the morphology of male gonostylus of all known species. The redescription of $A$. atrasetus (Rapp, 1945) in this work, is needed because of two synonymized taxa by QuATE and Brown (2004): A. lepidotus Quate, 1996 and A. stylofurcatus Collantes et Martinez-Ortega, 1999. All known figures of aedeagal complex of this species (incl. redescription of atrasetus of DucKHOUSE 1974) have some differences (see comments of QuATE \& Brown 2004, p. 79, however, not accepted by Ibañez-Bernal \& Suárez-Landa 2017, p. 19). A list of the world species of the genus Platyplastinx Enderlein, 1937 encompasses 13 known species from Brazil, Costa Rica, Ecuador, Florida and Panama (Quate 1999, Quate \& Brown 2004, Lopes \& Bravo 2015, Cordeiro 2020). 


\section{MATERIAL AND METHODS}

The material was collected with CDC miniature light-traps placed $1.5 \mathrm{~m}$ above the ground in the forest (compare JеžEK et al. 2011, p. 205, Fig. 81, JеžEK \& Le Pont 2016, p. 819, Fig. 25), v-vi.2009.

Study area (localities): Nicaragua: Caribbean side: Cerro Baka station, near El Empalme, RAAN department, Siuna municipality, patches of very damaged forest, $13^{\circ} 40^{\prime} 20.5^{\prime \prime} \mathrm{N} 84^{\circ} 30^{\prime} 21.1^{\prime \prime} \mathrm{W}$, altitude $200 \mathrm{~m}$ a.s.l. "Cerro Musun Natural Reserve" contains the mountain of the same name (altitude $1100 \mathrm{~m}$ a.s.l.), which is an isolated extinct volcano covered with primary forest. In the Penas Blancas mountainous Natural Reserve, part of the Cordillera Isabelia, station of La Laguna village, with a slightly degraded forest environment, $13^{\circ} 14^{\prime} 01^{\prime \prime} \mathrm{N} 85^{\circ} 44^{\prime} 55^{\prime \prime} \mathrm{W}$, altitude $870 \mathrm{~m}$ a.s.l. Waslala, station in a humid subtropical forest $10 \mathrm{~km}$ from the town, $13^{\circ} 19^{\prime} 52^{\prime \prime} \mathrm{N} 85^{\circ} 22^{\prime} 29^{\prime \prime} \mathrm{W}$, altitude $370 \mathrm{~m}$ a.s.l.

Specimens were preserved in the field using $70 \%$ ethanol. In the laboratory, specimens were cleared in chloralphenol, treated in xylol and mounted on glass slides in Canada balsam; types and voucher specimens are deposited in the National Museum, Natural History Museum, Department of Entomology, Prague, Czech Republic (NMPC). Slides are numbered with two separate series of numbers: Inv. No. = Inventory Slide Number of the family Psychodidae and Cat. No. = Catalogue Numbers of slides of types and historical specimens of Diptera (seе Ткос̌ et al. 2014).

Specimen observation, measurements and illustration. The maximum wing length is approximately equal to the distance from the line connecting the base of the basal costal node and neala to the wing apex. The ratios of the lengths of the femur, tibia and first tarsal segment of P1 (fore leg), P2 (middle) and P3 (hind) are indicated. Observations were made using Carl Zeiss Jena (Germany) and Reichert (Austria) microscopes, with a mirror arm as a drawing aid. The drawings were edited in Corel DRAW X6 and Corel PHOTO-PAINT X6 graphic software.

Morphological terminology for Diptera follows that of Cumming and Wood (2009, 2017), Wagner and Ibáñez-Bernal (2010), Curler (2020), ascoids sensu Kvifte and WaGNER (2017), ventral epandrial plate or sclerite are used as in Duскноuse (1990), epandrial clasping lobes as in SANTOS and CurLer (2014) which suggested this terminology and include that this is the same that has been called surstyli and cerci in previous papers on Psychodidae, and wing abbreviations $\mathrm{CuA}_{1}$ and $\mathrm{CuA}_{2}$ of STARK et al. (1999).

\section{Subfamily Psychodinae Tribe Maruinini}

\section{Arisemus atrasetus (Rapp, 1945)}

(Figs 1-18)

Psychoda atraseta Rapp, 1945: 310.

Arisemus atrasetus; Duckhouse, 1974: 58-60, figs 12-17; QuATe \& Brown, 2004: 78, 88.

Arisemus lepidotus Quate, 1996: 23-25, figs 9 d-g. (syn. by Quate \& Brown 2004)

Arisemus stylofurcatus Collantes et Martinez-Ortega, 1999: 216-218, figs 1-9. (syn. by QuAte \& BROWN 2004)

Redescription. Male. Head pyriform, flattened antero-posteriorly, vertex conspicuously elevated (Fig. 1), with shallow cleft apically, a little strangulated near upper ligament 
of pharynx, uniformly set with numerous setae alveoli. Horizontal border of setae above upper apices of eyes is slightly convex on both sides. Supraocular bristles above dorsal margins of eyes on both extreme sides of head are not developed. Eyes contiguous, kidney or C-shaped, eye bridge formed by 3 facet rows (Fig. 2). Dorsal and ventral apices of eyes are approximately of the same size. Frontoclypeus with two quite separated almost triangular alveoli patches near the basis of antennae. Antennae (Figs 3, 12) incomplete and digitate paired ascoids were not observed in contrast to the literature (DucкHOUSE 1974 -atrasetus, flagellomere 7-10, Quate 1996 - lepidotus, 8-11, Collantes \& Martínez-Ortega - stylofurcatus, 1-11). Scape cylindrical, 3.6 times as long as pedicel which is almost globular. Basal flagellomeres nodiform, with necks gradually a little prolonged in contrast to three apical bead-like smaller terminators without necks (the last flagellomere with conical apiculus sensu Duckhouse, Quate and Collantes \& Martínez-Ortega - see above). Mouthparts extending slightly beyond basal palp segment (Fig. 1). The lines of small spines between both labial lobes are not developed, however, with digital or scraper fused protuberances in between distally (Fig. 13). Length ratio of maxillary palps 1:1.3:1.3:2.1, segment 4 annulate (Fig. 4). The index of the maximum length of the cibarium to the length of the epipharynx is approximately 2.2:1. Labrum pointed, covered with microsetae (Fig. 5).

Thorax. Anepisternum setae patch approximately elliptic, however, with irregular distal margins, anepimeron with V-shaped patch (Fig. 6). Spiracles set up on mesothorax, closely separated from anterior region of anepisternum. No thoracic allurement organs. Wings lanceolate (Fig. 14), 1.9-2.3 mm long, pointed distally in the ending of $R_{5}$, a little expanded at the posterior margin, dark maculated. Infuscation free parts of wing: wing basis near neala and 11 semicircular flecks between vein endings (white gradually reduced patches, inconspicuous on the top of wing), with almost circular black spots near the wing margin. Following veins or their parts strengthened: $S c, R_{1}$ and $R_{2}$ (not basal cell, however, in connection with $\mathrm{R}_{3}$ and $\mathrm{R}_{4}$ more strengthened), $\mathrm{R}_{5}, \mathrm{CuA}$ and $\mathrm{CuA}$. Radial and medial fork complete, positioned as seen on Fig. 14. Wing index 2.4. Halteres (Fig. 7) almost ovoid with a prolonged stem. Ratio of maximum length of halteres to their maximum width approximately 2.9:1. Ratios of lengths of femora, tibiae and first tarsal segments $P_{1}$ 1.9:2.2:1.0, $\mathrm{P}_{2}$ 2.0:2.7:1.2, $\mathrm{P}_{3}$ 2.1:3.2:1.2. Paired tarsal claws of $\mathrm{P}_{1}$ bent distad, with a medial spine (Fig. 8).

Male genitalia. Aedeagal complex (Figs 10, 11, 18) asymmetrical with large basal, rounded paddle-shaped enlargement of ejaculatory apodeme proximally, inflated and keeled posteriorly, anteriorly dorso-ventrally flattened. Right paramere sickle-shaped, bifurcated in contrast to left one, which is blunt, aedeagus thin, dibble-shaped. Hypandrium (tergite 10) as a broad band between gonocoxites, conspicuous, almost V-shaped or triangular in the middle on both sides, divided proximally in the apex (Fig. 10). Gonocoxites inflated basally, approximately as long as gonostyles, which are forked, smaller appendage more than one-half length of main shaft (with conspicuous seta on the top), both sinuous and rounded apically (Figs 9, 17). Epandrium (Figs 15, 16) almost square-shaped, bare, with a single almost circular aperture placed in vertical axis basally. A rest of ventral plate forms two divergent arms connected proximally. Hypoproct tongue-shaped, epiproct only as a fold, both parts haired. Epandrial clasping lobes almost cylindrical, setose and bent (Figs 15, 16), almost twice as long as epandrium (measured with hypoproct), each with one apical tenaculum, frayed apically and strangulated a little in the middle.

Differential diagnosis. Arisemus atrasetus (Rapp, 1945) is morphologically similar to A. rubeni Bravo et Araújo, 2013 (male), however, some differences are as follows: scape cylindrical, 3.6 times as long as pedicel which is almost 


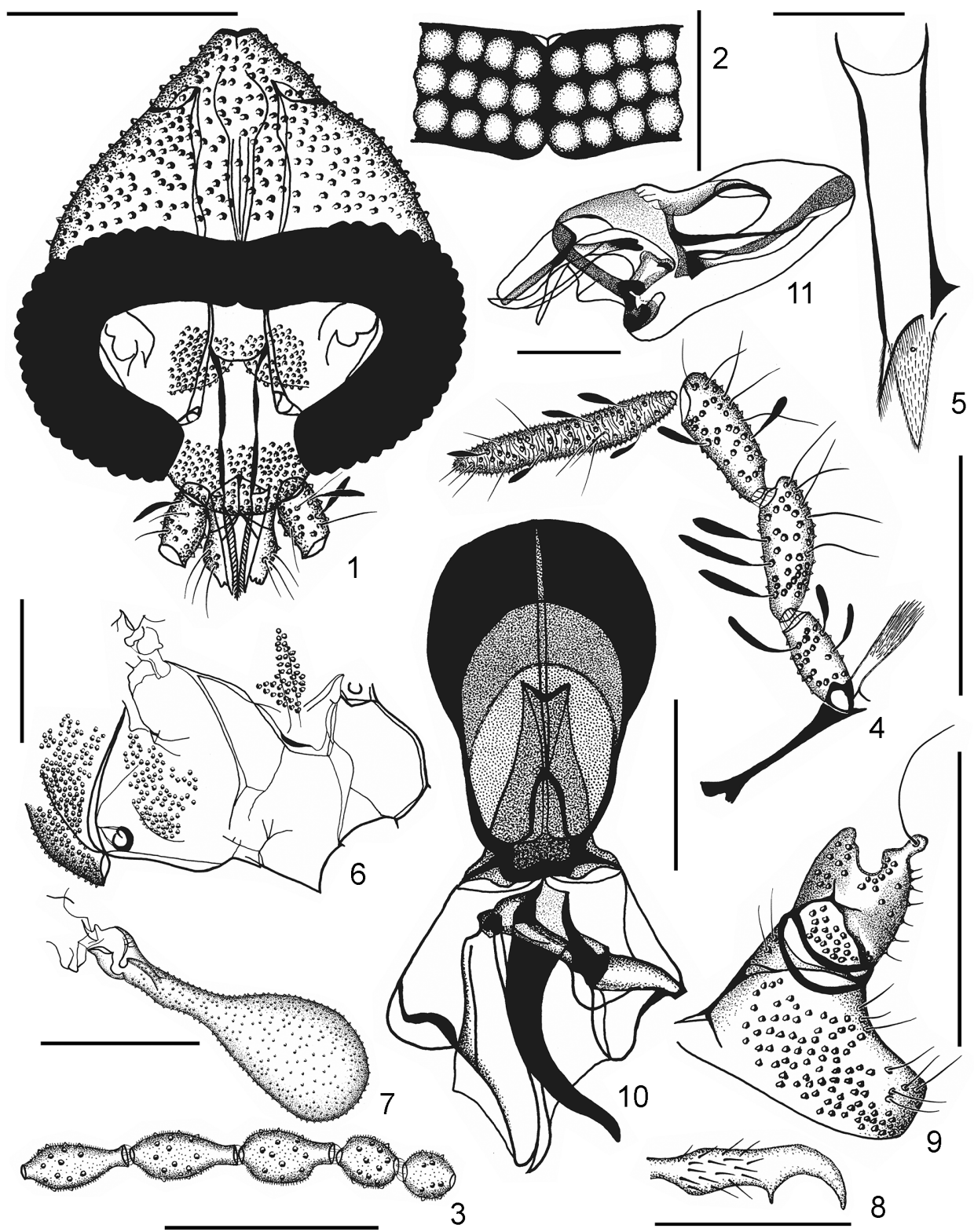

Figs 1-11. Arisemus atrasetus (Rapp, 1945), male. 1 = head, frontal view; 2 = frons and facets in detail, frontal view; $3=$ terminal flagellomeres (16th antennomere missing, not observed); $4=$ maxilla and palpus maxillaris; $5=$ cibarium, labrum and epipharynx; $6=$ thoracic sclerites, lateral view; $7=$ halter, lateral view; $8=$ tarsal claw of $\mathrm{P}_{1}$, lateral view; $9=$ gonopod, diagonal view; $10=$ aedeagal complex, dorsal view; $11=$ same, lateral view. Scale bars: $1,4,6,7,9=0.2 \mathrm{~mm} ; 2,3,5,10,11=0.1 \mathrm{~mm} ; 8=0.03 \mathrm{~mm}$ 
globular (Fig. 12), first flagellomere approximately 1.3 times as long as the second one, antepronotum without sensory organ near spiracle (Fig. 6). Wing index 2.4. Larger posterior margin of wing conspicuously infuscated as well as anterior part, endings of all long veins have rather small black patches (Fig. 14). Right paramere sickle-shaped, bifurcated in contrast to left one, which is blunt, aedeagus thin, dibble-shaped, a little longer than left paramere (Fig. 10, dorsal view). Bifurcated gonostyles with large U-shaped cleft between both protuberances (Figs 9, 17). Epandrium (Figs 15, 16) with a single aperture. Epandrial clasping lobes almost twice as long as epandrium, each with one apical tenaculum, strangulated a little in the middle.

A. rubeni Bravo et Araújo, 2013 can be distinguished by scape to pedicel ratio 1.5:1, scape pyriform, first flagellomere approximately twice as long as the second one (Bravo \& Araújo 2013, p. 86, Fig. 1B), antepronotum with pyriform sensory organ in front of thoracic spiracle (Bravo \& ARAújo 2013, p. 86, Fig. 1G). Wing index 3.0. A little expanded part of posterior margin of wing inconspicuously infuscated in contrast to anterior part, endings of all long veins have conspicuous black patches (Bravo \& Araújo 2013, p. 86, Fig. 1E). Aedeagus thin, shorter than parameres, S-shaped, sinuous, aedeagal complex as figured (Bravo \& ARAújo 2013, p. 86, Fig. 1H, dorsal view), bifurcated gonostyles without cleft between both protuberances, both parts attached together. Epandrium proximally with two foramina. Epandrial clasping lobes approximately as long as epandrium, apical tenaculum is not strangulated in the middle.

Material examined. Nicaragua: Cerro Baka station, coordinates $13^{\circ} 40^{\prime} 20.5^{\prime \prime} \mathrm{N}$ $84^{\circ} 30^{\prime} 21.1^{\prime \prime} \mathrm{W}$, altitude $200 \mathrm{~m}$ a.s.l., a small hill in the plain; landscape of large cattle meadows and thickets of degraded forest or coppice. Catches with CDC miniature light-traps, v.-vi 2009, Le Pont leg., 6 male (slides), several specimens dissected, Cat. No. 34915-34920, Inv. No. 25972-25977 (NMPC).

Bionomics. Unknown. Adults (males) collected in residual secondary forest, sometimes trampled by livestock.

Distribution. Costa Rica, Guatemala, Nicaragua, Panama.

\section{Arisemus venustus Ježek, Oboňa et Le Pont sp. n.}

(Figs 19-37)

Description. Male. Head (Fig. 19) longer than broad, vertex elevated, slightly sagitate. Frons hair patch irregularly sparse and well separated in a central stripe. Three supraocular bristles above dorsal margins of eyes on both extreme sides of head are developed. Eyes contiguous, kidney- shaped, eye bridge formed by 3 facet rows (Fig. 20). Dorsal and ventral apices of eyes are approximately of the same size. The basis of antennae is skirted by two quite separated almost trapezoidal alveoli patches. Antennae (Figs 21, 31) 
incomplete, paired digitate ascoids hardly evident (compare slide Inv. No. 25987, flagellomere 6). Scape conical, twice as long as wide, pedicel globular. First flagellar segment conspicuous, spindle-shaped, 1.4 times longer than following one, which has a short neck. Mouthparts extending beyond basal palp segment (Fig. 19). At the labellum, as shown in Fig. 32, miniature spines between both lobes are not visible. Labellum bulbose, with serrated margin in between distally. Length ratio of maxillary palps 1.0:1.2:1.5:2.3, segment 4 annulate (Fig. 22). Ratio of maximum length of cibarium to length of epipharynx (Fig. 23) 1.9:1, labrum pointed.

Thorax. Anepisternum setae patch missing, anepimeron with V-shaped patch (Fig. 33). Spiracles set up on mesothorax. Thoracic allurement organs present as a small hemisphaerical protuberances near spiraculum, pair of patagia on prothorax have a specific shape as a grooved capsule, orange coloured in ethanol, prolonged (1.4 times as long as diameter of spiraculum), with many miniature spines apically (Figs 24, 25, 33). Wings (Fig. 35) narrowly lanceolate, $1.9 \mathrm{~mm}$ long - holotype, paratypes $1.5-1.9 \mathrm{~mm}$, pointed distally in the ending of $\mathrm{R}_{5}$, inconspicuously expanded at the posterior margin, dark maculated. Main infuscation free parts of wing: wing basis near neala and basal cell, vicinity of Sc basally, small limited stripe between $\mathrm{R}_{1}$ and $\mathrm{R}_{2+3^{\prime}}$ mostly semicircular or oval flecks between vein endings (white gradually reduced 11 patches, very small on the top of wing), with oval black spots on the wing margin. Following veins or their parts strengthened: Sc conspicuously, $R_{1}$ and $R_{2}$ (not in basal cell, however, in connection with $R_{3}$ and $R_{4}$ more strengthened, with a supine parallel fold line), $\mathrm{R}_{5^{\prime}}, \mathrm{M}_{3^{\prime}}, \mathrm{CuA}$ and $\mathrm{CuA}_{2}$. Radial and medial fork complete (Fig. 35). Both forks are out of line with $\mathrm{CuA}_{2}$, medial fork positioned basally. Wing indices $\mathrm{AB}: \mathrm{AC}: \mathrm{AD}=9.5: 9.5: 8.8 ; \mathrm{BC}: \mathrm{CD}: \mathrm{BD}=1.0: 2.3: 3.3$. Wing index 3.1, medial wing angle $150^{\circ}$ (BCD). Knob of halteres (Fig. 34) almost globular with a prolonged stem. Ratio of maximum length of halteres to their maximum width approximately 3.0:1. Ratios of lengths of femora, tibiae and first tarsal segments $\mathrm{P}_{1}$ 2.1:2.4:1.0, $\mathrm{P}_{2}$ 2.2:3.0:1.4, $\mathrm{P}_{3}$ 2.4:3.6:1.4. Paired tarsal claws of $\mathrm{P}_{1}$ bent distad, pointed, with a medial blunt tubercle (Fig. 26).

Male genitalia. Aedeagal complex (Figs 29, 30, 36, 37) asymmetrical with rounded paddle-shaped ejaculatory apodeme inflated proximally and dorso-ventrally flattened. Right paramere sickle-shaped (Figs 29, 30, 36), left paramere thick and blunt (Figs 9, 36, 37), aedeagus pointed distally, approximately as long as both parameres, thin, with a very small bent inconspicuous overlap, closely adhering. Hypandrium as a very broad band between gonocoxites, conspicuously oval-shaped in the middle on both sides and shallow sclerotized cleft proximally (Fig. 29). Gonocoxites inflated basally, approximately as long as gonostyles, which are not forked, gradually tapering to the hooked top (Figs 29, 36). Epandrium (Figs 27, 28) almost square-shaped, bare, without aperture. A rest of ventral plate forms two divergent sclerotized arms not fused proximally. Hypoproct tongue-shaped, epiproct only as a fold, both parts haired. Epandrial clasping lobes almost cylindrical, setose and bent (Figs 27, 28), a little longer than epandrium (measured with hypoproct), each with one apical tenaculum, frayed apically.

Differential diagnosis. Arisemus venustus sp. n. is morphologically similar to A. grabhamana (Dyar, 1926) from Jamaica, however, male characters are quite different: scape 2.3 times as long as pedicel, pedicel gobular, without enlarged seta. Length ratio of maxillary palps 1.0:1.2:1.5:2.3 (Fig. 22). Pair of patagia on prothorax have a specific shape as a grooved capsule, orange coloured (observed fresh material in ethanol), prolonged (1.4 times as long as diameter of spiracle), with many miniature spines apically (Figs 24, 25, 33). 


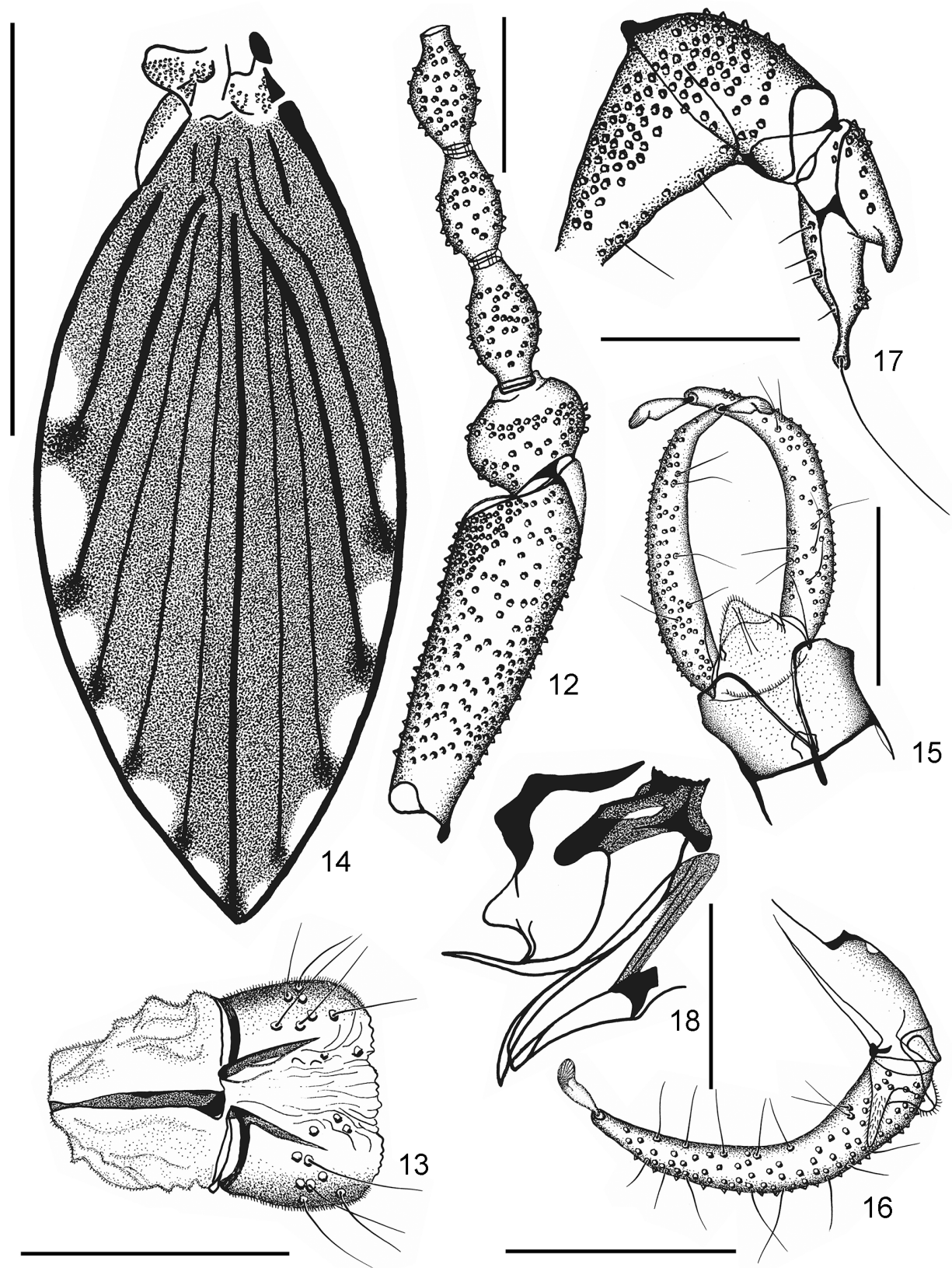

Figs 12-18. Arisemus atrasetus (Rapp, 1945), male. 12 = scape, pedicel and basal flagellomeres; 13 = terminal lobes of labium; $14=$ wing; 15 = epandrium and epandrial clasping lobes, dorsal view; 16 = epandrium and epandrial clasping lobe, lateral view; 17 = gonopod, lateral view; $18=$ distal part of aedeagal complex in detail, lateral view. Scale bars: $14=1 \mathrm{~mm}$; $15,16=0.2 \mathrm{~mm} ; 12,13,17,18=0.1 \mathrm{~mm}$ 
Wing index 3.1 (Fig. 35). Right paramere sickle-shaped (Figs 29, 30, 36), left paramere thick and blunt (Figs 9, 36, 37), aedeagus pointed distally from dorsal view (Figs 29, 37), rounded from lateral one (Fig. 36), approximately as

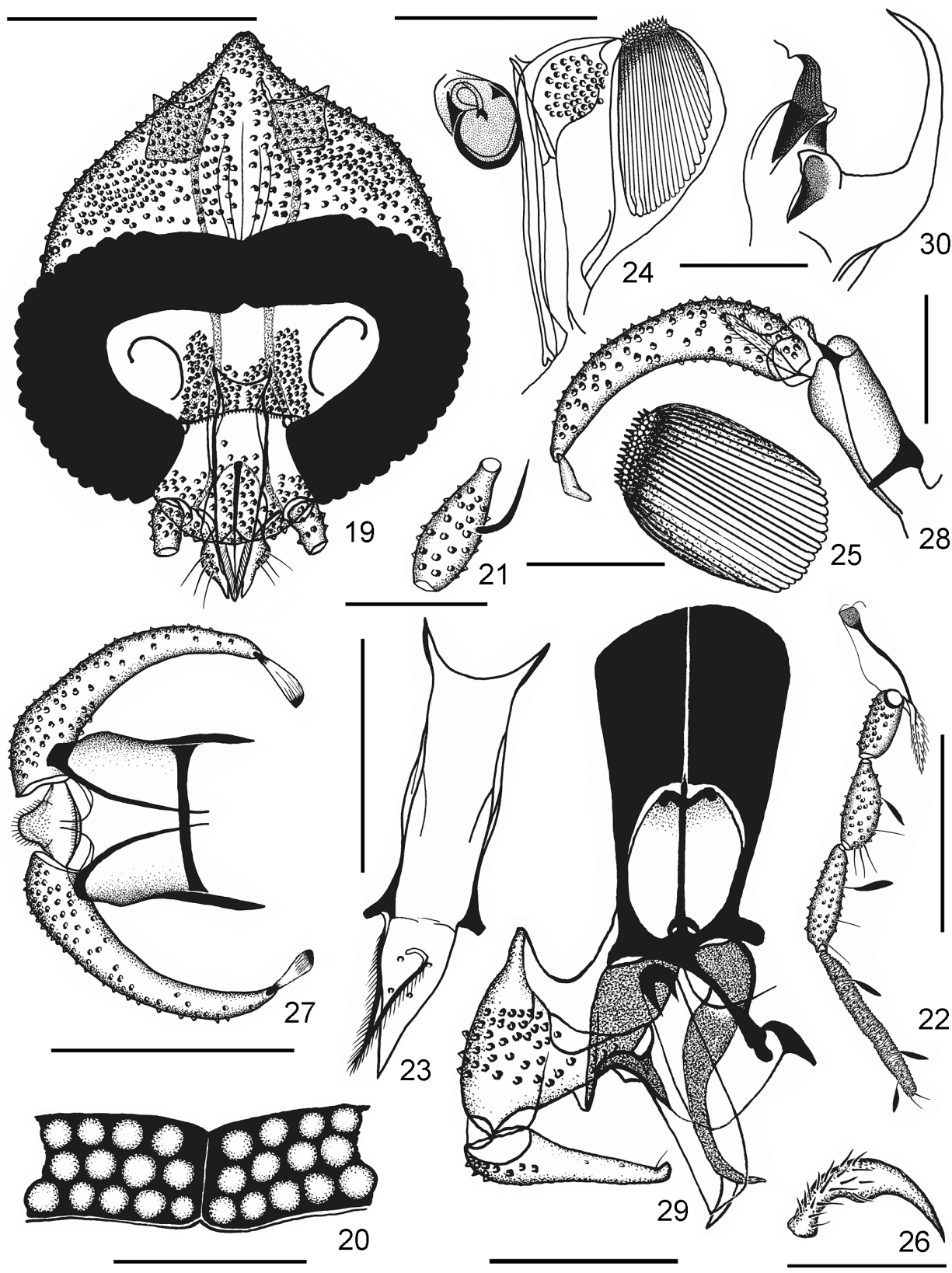


long as both parameres, thin, with a very small bent inconspicuous overlap, closely adhering to paramere (Figs 29, 37).

On the other hand, males of A. grabhamana (Dyar, 1926) have scape 2.1 times length of pedicel, pedicel eccentrical, enlarged medially and bearing a single enlarged seta. Length ratio of maxillary palps 1.0:1.2:1.7:2.0. Pair of patagia quite different, unclear examination (see comments on known morphology below). Wing index 2.0-2.5 (QuATE \& Brown 2004). One from parameres stepped near top, in right angle to aedeagus from dorsal view, without small bent inconspicuous overlap (compare SATCHELl 1955, p. 88, Fig. 2E and VAILLANT 1986, p. 335, Figs 4, 6).

Comments on patagia of grabhamana/maculosus (synonymy sensu DuckHOUSE 1974). Defined by SATChell 1955, p. 89, as conical protuberances above anterior spiracle - A. maculosus Satchell, 1955; DucкHоuse 1974, p. 149, as very tenuous sacs, each with a black central body, as large as anterior spiracle grabhamana; VAILlant 1986, p. 335, only by Fig. 3 ,stigmate prothoracique gauche et organes turgescents du même côté" without comments in the text - maculosus; QuATe \& Brown 2004, p. 81, in front of anterior spiracle, organ a dense cluster of berrylike granules, patch of long hairs behind anterior spiracle-grabhamana.

Type material. Holotype, male: Nicaragua: "Natural Reserve Cerro Musun", coordinates $12^{\circ} 97^{\prime} \mathrm{N} 85^{\circ} 24^{\prime} \mathrm{W}$, altitude $800 \mathrm{~m}$ a.s.l., catches with CDC light traps near the Research Station, subtropical forest, v.-vi.2009, Le Pont leg. Slide with a dissected specimen, Cat. No. 34921, Inv. No. 25978 (NMPC).

Paratypes 21 males (slides): The same locality, data and collector, several specimens dissected, Cat. No. 34922-34942, Inv. No. 25979-25999 (NMPC).

Type locality. Nicaragua: "Natural Reserve Cerro Musun", near the town of Rio Blanco (east of the Matagalpa Department).

Etymology. The specific epithet is derived from the Latin word „venustus - a - um" (adjective) $=$ gracefully refined; it refers to pair of characteristic patagia on prothorax (a grooved capsule, orange coloured, with many miniature spines apically).

Bionomics. Unknown. Adults (males) collected in an undergrowth forest, very steep, south-eastern side of Cerro Musun.

Distribution. Currently recorded only from Nicaragua.

Figs 19-30. Arisemus venustus Ježek, Oboňa et Le Pont sp. n., male. 19 = head, frontal view; 20 = frons and facets in detail, frontal view; 21 = a medial flagellomere in detail; 22 = maxilla and palpus maxillaris; 23 = cibarium, labrum and epipharynx; $24=$ thoracic spiracle and tuft of scales (only alveoli are marked) near patagium; 25 = patagium in detail; $26=$ tarsal claw of $\mathrm{P}_{1}$, lateral view; 27 = epandrium and epandrial clasping lobes, lateral view; $28=$ same, lateral view; $29=$ aedeagal complex and gonopod, dorsal view; $30=$ dissected right distal part of aedeagal complex in detail, lateral view. Scale bars: 19, 22, $27=0.2 \mathrm{~mm} ; 20,23$, $24,28,29=0.1 \mathrm{~mm} ; 21,25,30=0.05 \mathrm{~mm} ; 26=0.03 \mathrm{~mm}$ 


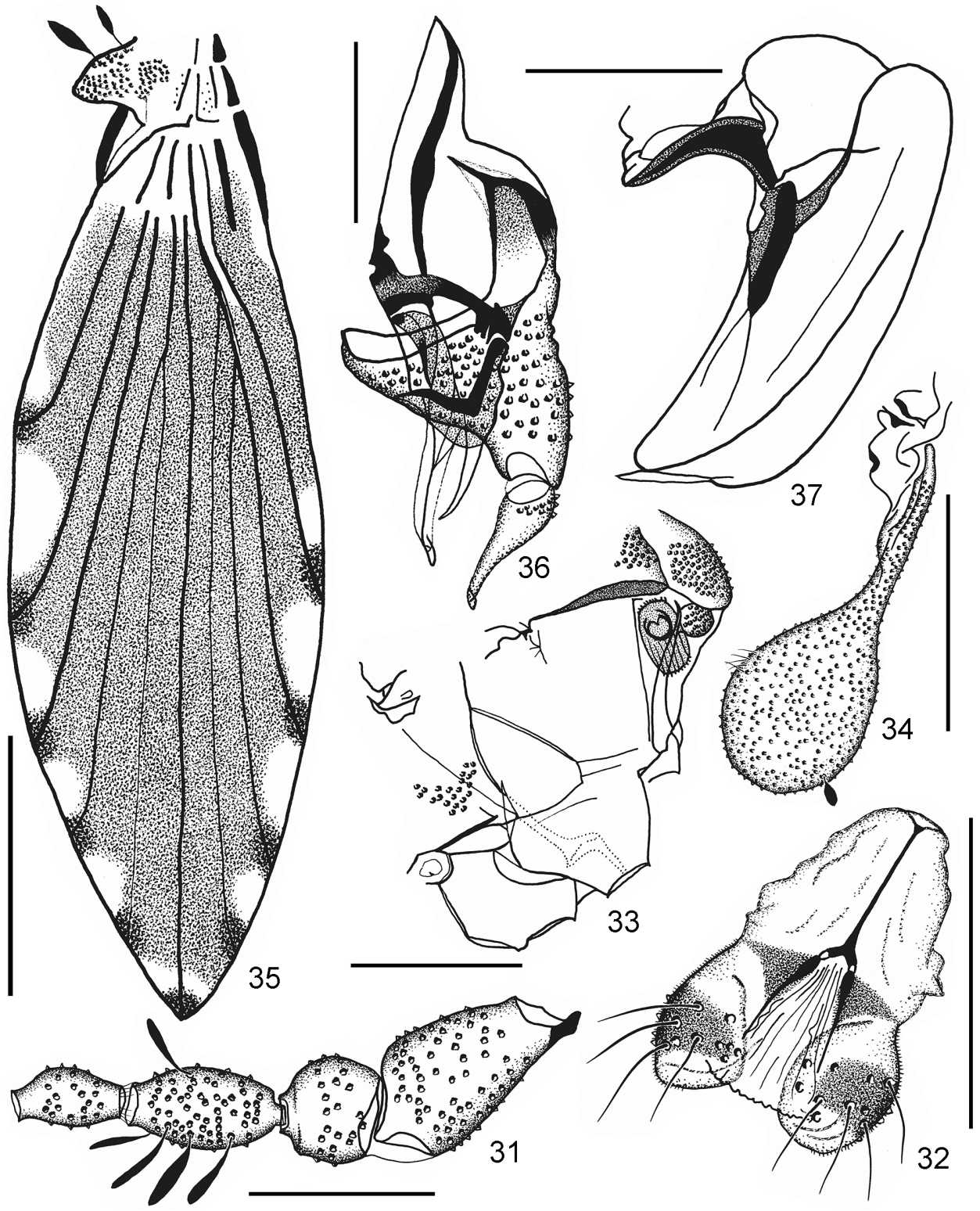

Figs 31-37. Arisemus venustus Ježek, Oboňa et Le Pont sp. n., male. 31 = scape, pedicel and basal flagellomeres; 32 = terminal lobes of labium; 33 = thoracic sclerites, lateral view; $34=$ halter, lateral view; 35 = wing; $36=$ aedeagal complex and gonopod, lateral view; $37=$ dissected left distal part of aedeagal complex in detail, lateral view. Scale bars: $35=0.5 \mathrm{~mm}$; $33,34=0.2 \mathrm{~mm} ; 31,32,36=0.1 \mathrm{~mm} ; 37=0.05 \mathrm{~mm}$ 


\section{Platyplastinx tango Quate et Brown, 2004 (Figs 38-54)}

Redescription. Male. Head (Fig. 38) almost rounded from frontal view (1.1 times broader in horizontal axis - measured without mouthparts), with raised concave bare tubercle dorsally and swollen kidney or C-shaped compound eyes laterally, contiguous in frontal area. Hair patch above close sparse and well separated in a central stripe. Ventral apices of eyes are broader than dorsal one. Eye bridge formed by 4 facet rows (Fig. 39). Supraocular bristles above dorsal margins of eyes on both extreme sides of head are not developed. Frontoclypeus with a dense triangular scar patch between and below the basis of antennae, cut terminally. Antennae (Figs 40, 49) of 16 articles. Scape (Fig. 49) cylindrical, 1.4 times as long as pedicel which is 1.3 times broader in horizontal axis (compare vertical one) and a little asymmetrical. Basal flagellomeres (Fig. 49) are spindle-shaped, 1.8 times as long as pedicel, however, 1.3 times narrower. Neck of postpedicel is not conspicuous, however, gradualy prolonged to the last flagellomere, which is symmetrical (Fig. 40) in contrast to the foregoing articles. Digital apiculus has a bulbose basis. Ascoids on flagellomeres 1-14 lanceolate (Figs 40,49), narrow, sinuous, almost twice as long as segments bearing them. Mouthparts extending slightly beyond basal palp segment (Fig. 38). At the labellum, as shown in Fig. 42, parallel lines of miniature spines between both lobes are not visible. Labellum bulbose, with digital protuberances in between (Fig. 42). Length ratio of maxillary palps 1.0:1.4:1.8:2.5, segment 4 not annulate (Fig. 41). Ratio of maximum length of cibarium to length of epipharynx 2.6:1 (Fig. 50), labrum pointed.

Thorax. Anepisternum setae patch approximately elliptic, however, with irregular distal margins, anepimeron with almost triangular patch (Fig. 43), katepisternum with irregular almost circular setae patch more widely spaced. Spiracles set low on mesothorax. No thoracic allurement organs. Wings broadly lanceolate (Fig. 52), 2.3-2.8 mm long, pointed distally in the ending of $R_{5}$, perceivable expanded at the posterior wing margin, irregularly and uniformly patterned mainly in a distal half of wing, with two black spots in basal clear area. Cross-vein $r_{2}-r_{4}$ conspicuous (in contrast to less visible cross-vein $\mathrm{m}_{1}$ $-\mathrm{m}_{3}$ ), transformed considerable black spot. The second black spot connecting $\mathrm{R}_{2+4^{\prime}} \mathrm{M}_{1}$ and basis of $\mathrm{R}_{5}$ forms distal margin of basal cell. Infuscation free parts of wing: large wing basis near neala and basal cell (Fig. 52), 9 semicircular or oval white spots between vein endings. Following veins or their parts strengthened: Sc conspicuously, $\mathrm{R}_{1}$ (not proximally), $\mathrm{R}_{2}$ distally, $\mathrm{R}_{5}, \mathrm{CuA}_{1}$ and $\mathrm{CuA}_{2}$. Wing index 2.4. Halteres (Fig. 51) almost cudgel-shaped with a prolonged stem. Ratio of maximum length of halteres to their maximum width approximately 3.1:1. Ratios of lengths of femora, tibiae and first tarsal segments $\mathrm{P}_{1}$ 1.5:1.6:1.0, $\mathrm{P}_{2}$ 1.6:1.8:1.0, $\mathrm{P}_{3}$ 1.7:2.2:1.6. Paired tarsal claws of $\mathrm{P}_{1}$ bent distally, hooked, with one medial tooth subapically and two medial rounded tubercles basally (Fig. 44).

Male genitalia. Basiphallus (ejaculatory apodeme) fan-shaped (Fig. 47), a little concave proximally as well as on both sides, distiphallus longly dibble shaped, inconspicuously sinuous, tapering distally and terminally pointed (Figs 48, 54). Paramere as a single shaft very narrow, much longer than distiphallus, strictured distally (Figs 47, 48, 54). Both parts of aedeagal complex closely adhering, enclosing and penetrating (see small aperture of paramere on Fig. 54), bent from lateral view. Gonocoxites, almost 1.2 times as long as cone-shaped gonostyli, which are bent, with a globular knob terminally (Figs 46, 47). Epandrium (Figs 45,53) broader than long, with paired oval foramens inconspicuously marked on outer sides, below with two large elliptical areas haired, narrowed medially but not touched. Hypandrium inconspicuous, narrow, as a slender band (Fig. 47). Hypo- 
proct largely tongue-shaped, covered with miniature microsetae in distal half, epiproct developed only as a bare fold (Figs 45, 53). Epandrial clasping lobes (Figs 45, 53) very short, almost pear-shaped, strengthened basally, haired, with one long pole-shaped tenaculum (approximately twice as long as clasping lobe) decorated by oval lacy ending. Moreover, 2-8 short apical peg-shaped accessory tenacula near are developed.

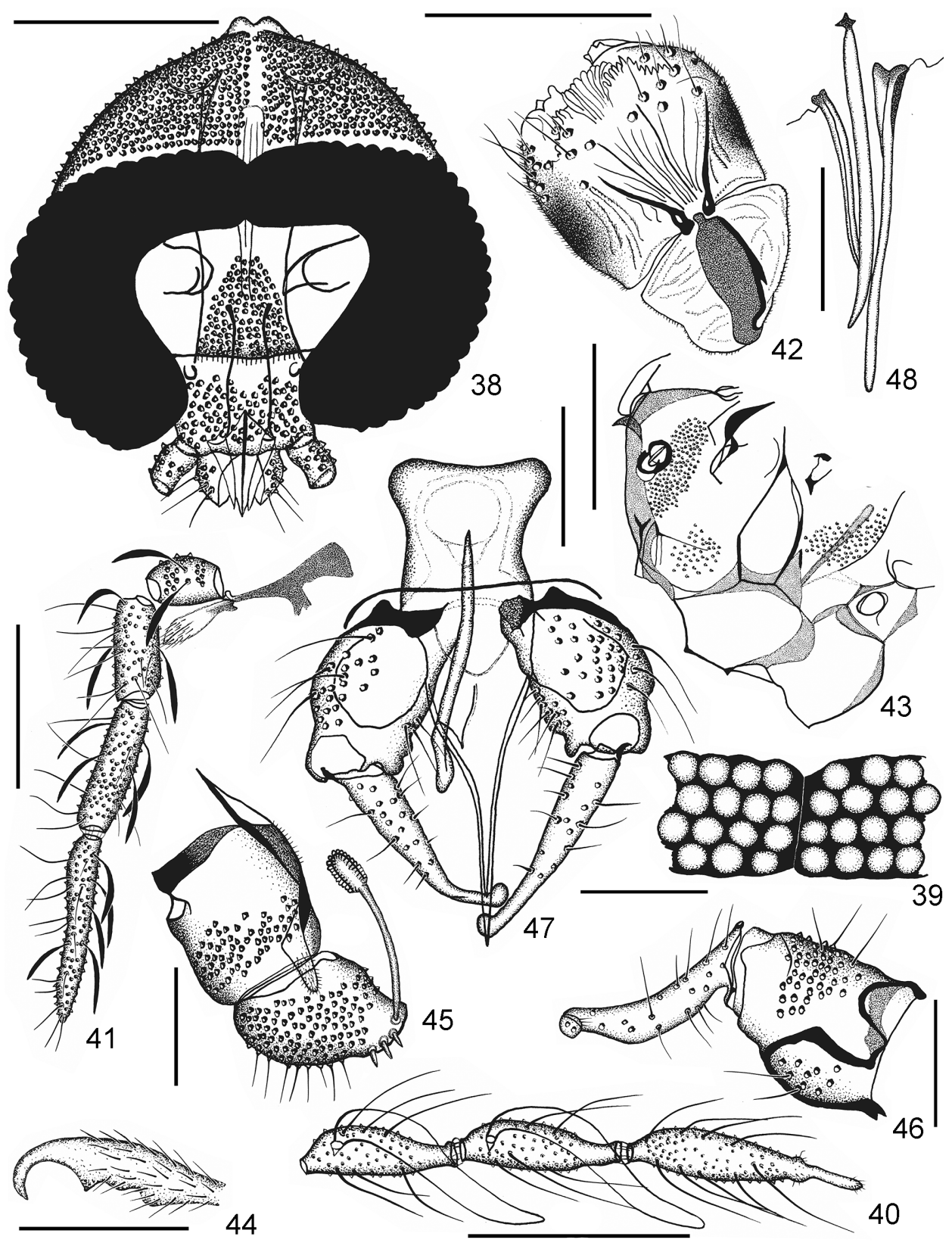




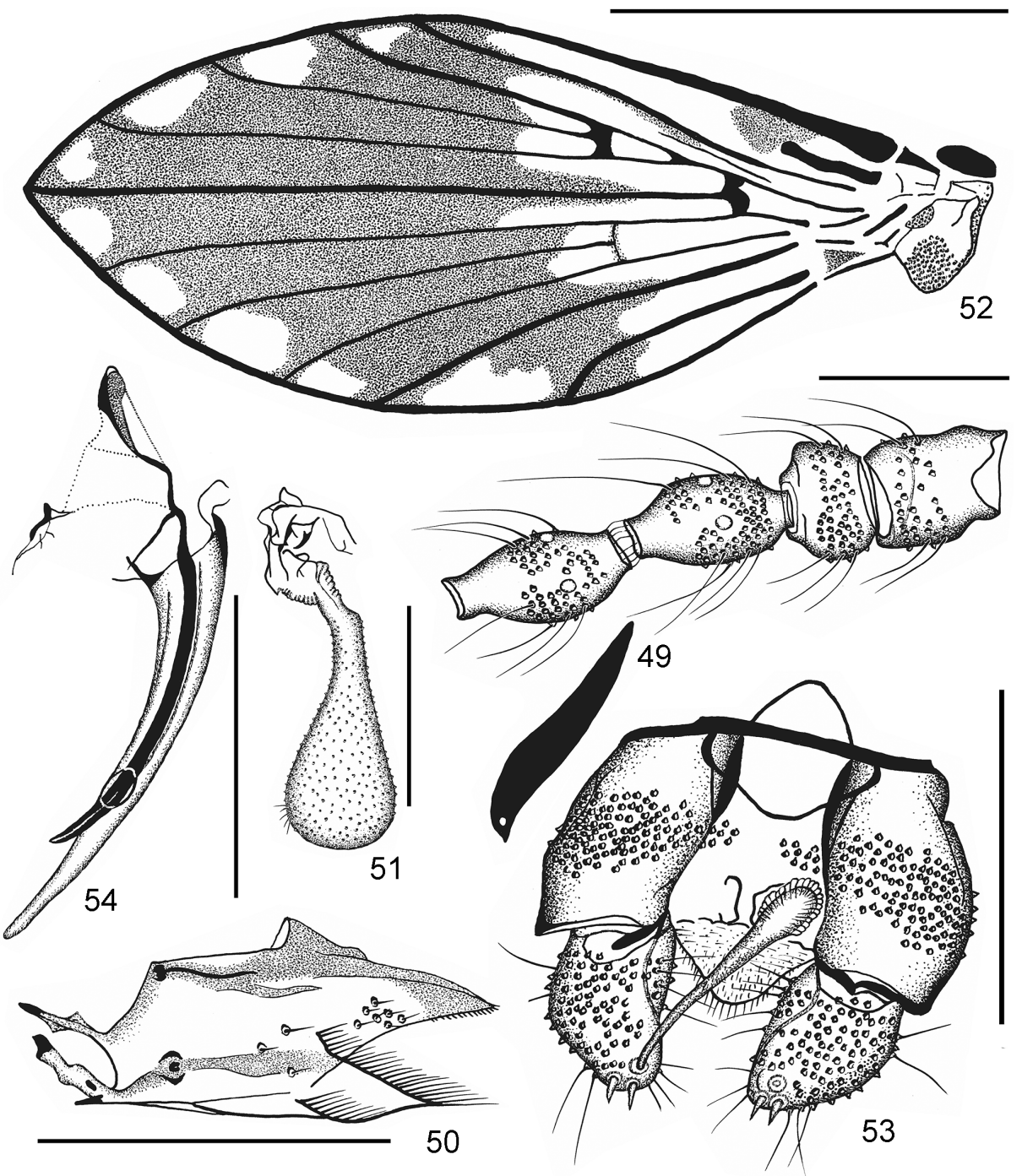

Figs 49-54. Platyplastinx tango Quate et Brown, 2004, male. $49=$ scape, pedicel, basal flagellomeres and dissected ascoid; $50=$ cibarium, labrum and epipharynx; 51 = halter, lateral view; 52 = wing; 53 = epandrium and epandrial clasping lobes, dorsal view; $54=$ aedeagal complex, lateral view. Scale bars: $52=1 \mathrm{~mm} ; 49-51,53,54=0.2 \mathrm{~mm}$

Figs 38-48. Platyplastinx tango Quate et Brown, 2004, male. 38 = head, frontal view; $39=$ frons and facets in detail, frontal view; $40=$ terminal flagellomeres and ascoids; $41=$ maxilla and palpus maxillaris; 42 = terminal lobes of labium; 43 = thoracic sclerites, lateral view; $44=$ tarsal claw of $\mathrm{P}_{1}$, lateral view; 45 = epandrium and epandrial clasping lobe, lateral view; 46 = gonopod, lateral view; 47 = aedeagal complex and gonopods, dorsal view; $48=$ distal part of aedeagal complex, inner view. Scale bars: $38,43=0.3 \mathrm{~mm} ; 40,41=0.2 \mathrm{~mm}$; 39, $42,45-48=0.1 \mathrm{~mm} ; 44=0.03 \mathrm{~mm}$ 
Differential diagnosis. Platyplastinx tango Quate et Brown, 2004 (male) is morphologically similar to P. moragai Quate, 1996, however, eye bridges are not separated (Fig. 39), terminal flagellomere has a digital apiculus with a bulbose basis and ascoids are lanceolate (Figs 40, 49). Frontoclypeus with a dense triangular scar patch between and below the basis of antennae, cut terminally (Fig. 38). Wing (Fig. 52) patterned mainly in a distal half of wing, with two black spots in basal clear area (cross-vein $r_{2}-r_{4}$ and distal margin of basal cell). Distiphallus longly dibble shaped, intense tapering apically and terminally pointed. Paramere as a single shaft very narrow, much longer than distiphallus, strictured distally (Fig. 47, 48, 54). Gonocoxites with a globular knob terminally (Figs 46, 47). Epandrium (Figs 45, 53) with two large haired elliptical areas and paired oval foramens. Epandrial clasping lobes (Figs 45, 53) almost pear-shaped, with one long pole-shaped tenaculum decorated by oval lacy ending and 2-8 short apical peg-shaped accessory tenacula.

In contrast to the mentioned species, $P$. moragai has eye bridges separated by less than one half facet diameter (Quate \& Brown 2004, p. 69, Fig. 176) and terminal flagellomere without a bulbose basis of digital apiculus, ascoids are unidigitate (see Quate 1996, p. 35, Fig. 13i). Hair patch on frontoclypeus quadrate. Wing (Quate 1996, p. 35, Fig. 13h; Quate \& Brown 2004, p. 69, Fig.

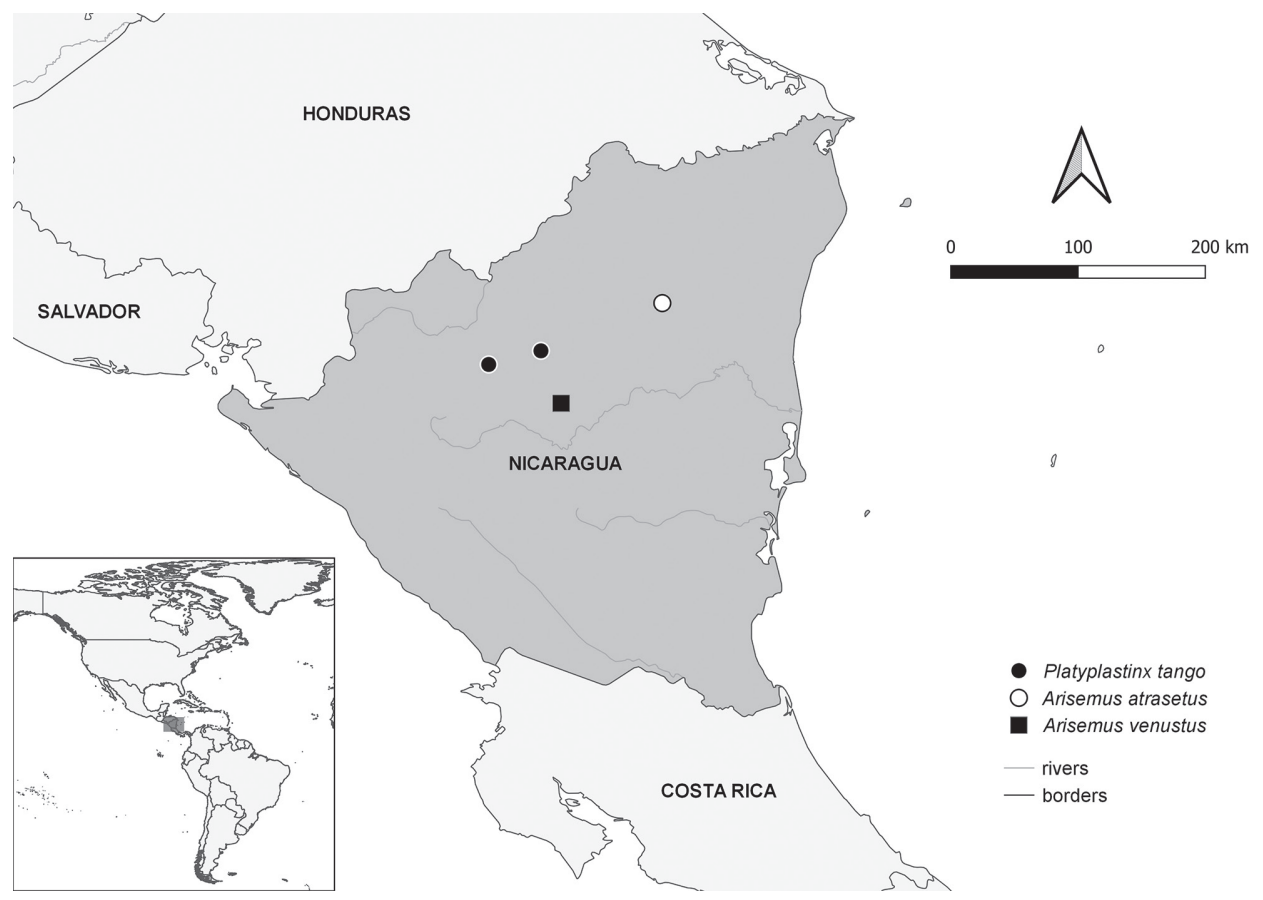

Fig. 55. Map of the collecting areas 
174) almost completely infuscated, with black spots limited only on basis of $R_{5}$ and endings of all veins. Distiphallus longly tongue-shaped, tapering to shoe-like apex a little beyond apex of paramere (see Quate \& BROwn 2004, p. 69, Fig. 173). Gonocoxites without a conspicuous globular knob terminally. Epandrium bare, with single oval aperture proximally (see QuATE 1996, p. 35, Fig. 13f). Epandrial clasping lobes almost cylindrical, with one conspicuous brush-shaped tenaculum and 3-6 inexpressive apical rods or peg-shaped accessory tenacula near (Quate 1996, p. 36; QuATE \& BRown 2004, p. 70).

Material examined. Nicaragua: Waslala, in the Atlantico Norte Department, station in an ecotonal forest/coffee plantation, $13^{\circ} 19^{\prime} 52^{\prime \prime} \mathrm{N} 85^{\circ} 22^{\prime} 29^{\prime \prime} \mathrm{W}$, altitude $370 \mathrm{~m}$ a.s.l., 5 males. One additional male comes from "Penas Blancas Natural Reserve", station La Laguna village, $13^{\circ} 14^{\prime} 01^{\prime \prime} \mathrm{N} 85^{\circ} 44^{\prime} 55^{\prime \prime} \mathrm{W}, 870 \mathrm{~m}$ a.s.l. All material collected by CDC miniature light-traps, v.-vi.2009, Le Pont leg. and slided, several specimens dissected, Cat. No. 34943-34948, Inv. No. 26000-26005 (NMPC).

Bionomics. Unknown. The adults (males) collection station was located at a primary forest / coffee plantation ecotone, in a hilly landscape, very humid, in Waslala; in Penas Blancas slightly degraded subtropical forest.

Distribution. Costa Rica, new for Nicaragua.

The subfamily Psychodinae was represented in Nicaragua by 54 species so far (Duckhouse 1973, Maes \& Killick-Kendrick 1990, Collantes \& Martinez-Ortega 1999, Quate \& Brown 2004, Tкос̌ et al. 2017, Ježek et al. 2020). A list of Psychodine moth flies increases by Arisemus venustus sp. n. and Platyplastinx tango Quate et Brown, 2004 collected in Nicaragua to 56 species, the last-mentioned genus represents the first record for this country. Arisemus venustus sp. n., described here, increases the number of known species of Arisemus to 34 . The genus Platyplastinx Enderlein, 1937 was not known so far from Nicaragua.

Acknowledgements - The specimens were collected on the basis of permission from 31.iv.2009 provided by the Entomological Museum (MEL) of Leon, Nicaragua; exportation permit of entomological samples to the National Museum of Natural History, Paris: Autorización especial DGPN/DB-012-2009 was provided by Ministerio del Ambiente y los Recursos Naturales, Direccion especifica de biodiversidad, Managua. We are grateful to the management of the Entomological Museum in Leon, for authorizing us to collect in Cerro Musún Natural Reserve in June 2009. We are indebted to Camilo Fuentes for his help during fieldwork, and we thank the team of the Marena Lodge Station on the Cerro Musún, for their assistance. Our thanks are due to Aleš Bezděk (Czech Academy of Sciences, České Budějovice, Czech Republic), who kindly informed us about updated references in the literature. We would especially like to thank the anonymous reviewers who helped 
by providing constructive comments and improving the manuscript. The study was supported by the Ministry of Culture of the Czech Republic (DKRVO 2020-2023/5.I.c, National Museum, Prague, 00023272).

\section{REFERENCES}

Bejarano, E. E. \& Estrada, G. L. (2016): Family Psychodidae. - Zootaxa 4122: 187-238. https://doi.org/10.11646/zootaxa.4122.1.20

Botosaneanu, L. \& Vaillant, F. (1970): Trois diptères Psychodidae nouveaux de Cuba. Travaux du Laboratoire d'Hydrobiologie 61: 173-183.

Bravo, F. \& Araújo, M. X. (2013): Two new species of moth flies (Diptera, Psychodidae) from the semi-arid region of Brazil. - Zootaxa 3693: 85-90.

https://doi.org/10.11646/zootaxa.3693.1.6

Collantes, F. \& Baquero, E. (2000): First record of the subfamily Psychodinae (Diptera: Psychodidae) from Ecuador. - Aquatic Insects 23(4): 277-281.

https://doi.org/10.1076/aqin.23.4.277.4878

Collantes, F. \& Martinez-Ortega, E. (1999): A new species of moth-fly belonging to genus Arisemus Satchell, from Nicaragua (Diptera, Psychodidae). - Aquatic Insects 21(3): 215-219. https://doi.org/10.1076/aqin.21.3.215.4520

Cordeiro, D. P. (2020): First record to Brazil of one genera and seven species of Psychodidae (Diptera) with further new records for 10 countries on the Neotropics. - Papeis Avulsos de Zoologia (São Paulo) 60: 1-10. https://doi.org/10.11606/1807-0205/2020.60.02

Cumming, J. M. \& Wood, D. M. (2009): Adult morphology and terminology. Pp. 9-50. In: Brown, B. V., Borkent, A., Cumming, J. M., Wood, D. M., Woodley, N. E. \& Zumbado, M. A. (eds): Manual of Central American Diptera. Vol. I. - NRC Research Press, Ottawa.

Cumming, J. M. \& Wood, D. M. (2017): Adult morphology and terminology. Pp. 89-133. In: Kirk-Spriggs, A. H. \& Sinclair, B. J. (eds): Manual of Afrotropical Diptera. Vol. 1. Introductory chapters and keys to Diptera families. - South African National Biodiversity Institute, Pretoria.

Curler, G. (2020): Descriptions of two new genera of Maruinini (Diptera, Psychodidae, Psychodinae) from the Mitaraka range of French Guiana. In: Touroult, J. (ed.): “Our Planet Reviewed" 2015 large-scale biotic survey in Mitaraka, French Guiana. -Zoosystema 42(10): 139-149. https://doi.org/10.5252/zoosystema2020v42a10

Dyar, H. G. (1926): Some apparently new American psychodids (Diptera, Psychodidae). Insecutor Inscitiae Menstruus 14(7-9): 107-111.

Duckhouse, D. A. (1973): A catalogue of the Diptera of the Americas south of the United States. 6A. Family Psychodidae, subfamilies Bruchomyiinae, Trichomyiinae, Sycoracinae and Psychodinae. - Museu de Zoologia, Universidade de São Paulo, 29 pp.

Ducкноuse, D. A. (1974): Redescription of the Neotropical Psychodidae (Diptera, Nematocera) described by Knab, Dyar and Coquillet. - Journal of Entomology (B) 42(2): 141-152. https://doi.org/10.1111/j.1365-3113.1974.tb00067.x

Duckhouse, D. A. (1990): The Australasian genera of Pericomoid Psychodidae (Diptera) and the status of related Enderlein genera in the Neotropics. - Invertebrate Taxonomy 3: 721-746. https://doi.org/10.1071/IT9890721

Enderlein, G. (1937): Klassification der Psychodidae (Dipt.). - Deutsche entomologische Zeitschrift 1936: 81-112. https://doi.org/10.1002/mmnd.48019360301 
Ibañez-Bernal, S. \& SuÁrez-Landa, M. T. (2017): First record of the genus Arisemus Satchell in Mexico, with description of Arisemus imeldae sp. nov. (Diptera: Psychodidae). - Dugesiana 24: 17-23.

Ježer, J. \& Le Pont, F. (2016): Psychodidae (Diptera) of New Caledonia: checklist and description of a new genus and species. - Acta Entomologica Musei Nationalis Pragae 56(2): 813-826.

Ježek, J., Le Pont, F., Martinez, E. \& Mollinedo, S. (2011): Three new species of non-biting moth flies (Diptera: Psychodidae: Psychodinae) from Bolivia, with notes on higher taxa of the subfamily. - Acta Entomologica Musei Nationalis Pragae 51(1): 183-210.

Ježé, J., ОвoňA, J., Le Pont, F., Maes J.-M. \& Martinez, E. (2020): Redescription of Armillipora Quate (Diptera: Psychodidae: Psychodinae) with a new species from Bolivia. - Zootaxa 4890: 417-427. https://doi.org/10.11646/zootaxa.4890.3.8

Kvifte, G. M. \& Wagner, R. (2017): 24. Psychodidae (Sand Flies, Moth Flies or Owl Flies). Pp. 607-632. In: Kirk-Spriggs, A. H. \& Sinclair, B. J. (eds): Manual of Afrotropical Diptera. Vol. 2. Nematocerous Diptera and lower Brachycera. Suricata. Vol. 5. - South African National Biodiversity Institute, Pretoria.

Lopes, P. S. \& Bravo, F. (2015): Review of Platyplastinx Enderlein, 1937 (Diptera, Psychodidae) with descriptions of four new species. - Zootaxa 4048: 583-593. https://doi.org/10.11646/zootaxa.4048.4.9

Maes, J. M. \& Killick-Kendrick, R. (1990): Catálogo de los Diptera de Nicaragua. 2. Psychodidae (Nematocera). - Revista Nicaragüense de Entomologia 14: 5-15.

Quate, L. W. (1996): Preliminary taxonomy of Costa Rican Psychodidae (Diptera), exclusive of Phlebotominae. - Revista de Biologia Tropical 44(Suppl. 1): 1-81.

Quate, L. W. (1999): Taxonomy of Neotropical Psychodidae (Diptera) 3. Psychodines of Barro Colorado Island and San Blas, Panama. - Memoirs on Entomology International 14: 409-441.

Quate, L. W. \& Brown, B. V. (2004): Revision of Neotropical Setomimini (Diptera: Psychodidae: Psychodinae). - Contribution in Science: Natural History Museum of Los Angeles 500: 1-117.

RApr, W. F. (1945): New Psychodidae from Barro Colorado Island. - Journal of the New York Entomological Society 53: 309-311.

Santos, B. C. \& Curler, G. (2014): Four new species of Tonnoira Enderlein (Diptera: Psychodidae: Psychodinae) from the Brazilian Atlantic forest. - Zootaxa 3760(3): 463-470. https://doi.org/10.11646/zootaxa.3760.3.13

Satchell, G. H. (1955): Two new subgenera of Psychodidae (Diptera) from Jamaica, with descriptions of five new species. - Annals and Magazine of Natural History 12: 85-93. https://doi.org/10.1080/00222935508651831

Stark, J., Bonacum, J., Remsen, J. \& De Salle, R. (1999): The evolution and development of Diptera wing veins: a systematic approach. - Annual Review of Entomology 44: 97-129. https://dx.doi.org./10.1146/annurev.ento.44.1.97

Ткос̌, M., Ježек, J. \& Le Pont, F. (2017): Alepia bifida, a new species of moth flies from Central America (Diptera: Psychodidae: Psychodinae). - Acta Entomologica Musei Nationalis Pragae 57(2): 765-774. https://doi.org/10.1515/aemnp-2017-0099

Ткос̌, M., Pecharová, M. \& JežEк, J. (2014): Catalogue of the type specimens of Diptera deposited in the Department of Entomology, National Museum, Prague, Czech Republic. Moth flies (Psychodidae). - Acta Entomologica Musei Nationalis Pragae 54: 789-837.

Vaillant, F. (1986): Le genre Arisemus Satchell et quelques genres voisins (Diptera, Psychodidae). - Nouvelle Revue d'Entomologie (N.S.) 3: 333-340. 
Wagner, R. \& Ibáñez-Bernal, S. (2010): Psychodidae (sand flies, and moth flies or owl flies) 19. Pp. 319-335. In: Brown, B. V., Borkent, A., Cumming, J. M., Wood, D. M., Woodley, N. E. \& Zumbado, M. (eds): Manual of Central American Diptera, Vol. 1 (2009). - National Research Council of Canada, Ottawa.

Wagner, R. \& Joost, W. (1994): On a small collection of Psychodidae (Diptera) from Colombia. - Studies on the Neotropical Fauna and Environment 29: 75-86. https://doi.org/10.1080/01650529409360920

Wagner, R. \& Masteller, E. C. (1996): New moth flies (Diptera: Pychodidae) and a key to species from Puerto Rico. - Proceedings of the Entomological Society of Washington 98: $450-464$.

Received January 6, 2021, accepted July 6, 2021, published November 19, 2021 